\title{
Green Supply Chain Collaboration and Incentives: Current trends and future directions
}

\begin{abstract}
This editorial piece discusses the current trends and future research directions in green supply chain collaboration and incentives. The discussion begins with evolution of green supply chain collaborations and few contributions made so far. The editorial piece introduces the special issue papers which address the green collaboration challenges and offers a general framework suggesting pathways for future research. The article ends with the open research questions in green supply chain collaborations and incentives.
\end{abstract}

Keywords: Green supply chain; collaboration; incentives; further research

\section{Introduction}

Supply chain collaboration is a relationship between supply chain partners developed over a period of time to achieve lower cost, higher quality, greater product innovation, reduce risks and enhance market value. In addition to the above benefits, recent happening to some of the focal companies such as Nike, Satyam Computer Services, and Coca-Cola in terms of workforce-related malpractice, corporate fraud, non-compliance on environmental issues created numerous pressures to the focal company from governing agencies, customers and stakeholders to be socially responsible. These pressures make focal companies to push their boundaries and make them to collaborate with their members to asses and ensure they are socially responsible. Latest version of greenness in supply chain refers to the responsibility of members or firms to ensure coordination for environmental, social and ethical compliance from upstream to downstream members. It is very well reported that green collaboration requires a substantial commitment of resources and organizational capabilities. Hence the basic question lies among researchers and practitioners is how focal companies should collaborate to become greener.

Collaboration is dependent on the provision of mutual benefit. Furthermore, it is not quite clear how upstream members are going to be benefited through green initiatives of focal companies. It's obvious that the focal companies are going to be benefited with the green initiatives. Hence the challenging questions for the focal company is how they should design incentive structures for green initiatives and interestingly how should they reward policy appropriately across the members in supply chain. 
This special issue specifically attempted to address the following basic three challenging open questions with respect to green supply chain collaboration and incentives:

- How focal companies should collaborate to become greener?

- How focal company should design incentive structures for green initiatives?

- How should the focal company reward policy appropriately across the members in supply chain?

Suggested topics to this special issue are as follows: Resources and organizational capabilities requirements for green collaboration, Buyer-supplier green relationship, Guanxi and green collaboration, Drivers and barriers for green supply chain collaboration, Incentive mechanism and supply chain network cooperative performance, Environmental management practices and incentives, Green knowledge management and rewards, Eco innovation and green supply chain collaboration, Remanufacturing and balanced incentive strategies, Organizational proactive environmental management strategies and joint decision making, Supply chain integration and green collaboration, Influence of recent technology on green supply chain collaboration, Cultural aspects in green collaboration, Role of trust and belief, Environmental supplier selection and supplier monitoring and Technology sharing and incentives.

\section{Evolution of green supply chain collaboration}

To trace the evolution of green supply chain collaboration we searched Scopus and EBSCO databases using keyword "green supply chain collaboration" within title, abstract and keywords during last five years. Interestingly we find 15 articles, with help of the key articles we tried to understand the pathway for green collaboration starting from green benefits, green integration, green relationship and green practices on performance.

\section{Green benefits}

It is well known that benefits drives collaboration. Conventional supply chain collaboration would lead to economic benefits for the focal company and in turn, the focal company will share that gain among the supply chain members in an appropriate way. However, green supply chain collaboration would lead to green benefits for the focal company which cannot be realized immediately and normally considered as a long term effect. It is not well known 
how the green benefits can be shared among the members. Green collaboration benefits listed out in the previous studies are reduction of business waste (Azevedo et al., 2011), environmental impact (reducing pollutant emission, using renewable energy sources, avoiding the use of toxic substances, and using environmentally friendly materials), market performance (access to new markets; competitive advantage), corporate image performance (reputation; regulatory compliance), manufacturing performance (efficiency in the use of materials; energy efficiency, innovation), financial performance(Increased margins or market share; customers willingness to pay a premium price for products)and supply chain cost (Dangelico and Pontrandolfo, 2013). The overall benefits out of green collaboration reside with the focal companies and few studies reported the burden to the upstream suppliers. Specifically upstream suppliers in emerging economy context will suffer a lot due to green collaboration without any additional benefits (Chen and Hung, 2012).Out of 15 articles, one article discussed the benefits of reverse revenue sharing contract in downstream supply chain to improve the coordination between manufacturers and retailers to collect back the used materials for collaborative manufacturing (De Giovanni, 2011).

\section{Green relationship}

Relationship is the essential aspect for achieving collaboration. Few papers published so far discussed the importance of relationship. Sheu (2014) discussed the joint value creation and the complementary effects gained through green collaborative relationship. Relationship is based on its immediate value of the outcome in conventional settings. However, in the green supply chain context it differs where the upstream and downstream members have to strengthen the engagement with the focal companies based on certain long term agreements, good will and trust. If we view relationship in terms of dependency and certainties variables, researchers started viewing green relationship from the view of economic, technological and political elements (Vachon, 2007). Similarly, under certainties few researchers attempted to discuss the role of contractual and competence elements (Vachon and Klassen, 2008; Sheu, 2011; Chen and Huang, 2012; Cheng 2011; Gavronski et al., 2011; Dangelico and Pontrandolfo, 2013).Few articles have attempted to discuss the constraints of inter-firm relationship such as bargaining process to move towards green supply chain coordination and the role of interdependence between producer and retailer through third party intervention (Sheu, 2011; 2014; Green 2012). 


\section{Green integration}

Traditionally integration refers how the business processes between inter organizations are aligned within supply chain to create synergy and to achieve synchronized actions. Integration is one among the enablers besides relationship to achieve collaboration. Similarly, it is important to know green thinking is aligned among the supply chain members process and products. Previous studies so far acknowledged the importance of capabilities development within focal companies and suggested how it will be helpful to achieve collaboration with different type of actors (Dangelico and Pontrandolfo, 2013; Gavronski et al., 2011). It is rare to find a study which discusses how green external integration can be achieved similar to ones like Keiretsu process.

\section{Green practices}

Practices to achieve green benefits have been well reported in the literature. Azevedo et al. (2011) studied the relationship between green practices and firm performance. They studied the effect of greening the supply process practices, advanced green practices, product based green practices and greening the delivery process on combined performance system. Usha et al. (2014) discussed the influence of various pressures to manufacturers, upstream suppliers and downstream distributors to reduce carbon emission. Using exploratory study of Canadian and North America firms, Vachon (2007) examined the linkages between green supply practices and the selection of environmental technologies. Later on, Vachon and Klassen (2008) investigated the relationship between environmental collaborative practices such as joint environmental goal setting, shared environmental planning and working together to reduce environmental impacts on manufacturing performance. Similarly, Koh et al. (2012) studied the variation of environmental management diffusion among supply chain members and the effect of environmental management system adaption.

\section{Introduction to special issue papers}

We received about 40 papers to our call and finally we selected 11 papers after rigorous review process. Brief overview of selected papers with respect to green benefits, green relationship, green integration and green practices to achieve green supply chain collaboration with incentives is given below 


\section{Green benefits}

Ala-Harja and Helo used a performance measurement framework to analyses green logistics decision in food industry and compared it with various financial and environmental metrics. They compare supply chain decisions and analyze where environmental effects are improving, together with cost efficiency and on-time delivery performance, and when the impacts point to different directions. The paper presents three case studies and an analysis of the performance measures. Finally, they have developed a framework with three decision types such as supply chain structure (supplier selection, plant location), logistics media (transportation mode, packaging materials, and packaging size) and planning and timing structures. They compared the tradeoff between operational efficiency impact and emission impact.

Green supply chain management has emerged as a key strategy for organizational sustainability. Azadi et al. proposed two data envelopment analysis approaches to determine targets for two-stage network structures.. The proposed procedure is a methodological contribution and will be a useful tool for managers to set targets and monitor the performance of green supply chain performance through green transportation. They argue that monitoring, evaluating, benchmarking, and planning for partners in supply chain will bring a variety of green supply chain benefits to management and company.

\section{Green relationship}

The buyer-seller relationships including other relationships in supply chains are critical for the success of achieving a green supply chain and its performance. The study by Luo et al. analyzed the role of Guanxi between buyer-seller and its impact on green performance in China. This study captured the role of cultural aspects and inter-personal relationships between suppliers and manufacturers and its influence on green performance. This empirical research investigates the impact of asset specificity, volume uncertainty, transaction frequency and competition to green supply chain collaboration. The empirical study findings from the emerging country perspective are interesting and show how good buyer-supplier relationship can enhance green supply chain relationships and how it can be expanded to other emerging economies such as Vietnam and Malaysia. 
Green supply chain and logistics have become a major focus in both manufacturing and services. Participating members along the supply chain operations demand a balance between economic and environmental interests. Lun et al. explored the logistics service providers greening capability practices. According to them, the green propensity is the involvement of customers in performing logistics service activities to achieve environmental performance. They have attempted to understand the status of logistics service providers with a greening propensity to adopt green operations, for carrying out their business activities and the relationship between green capability and firm performance in terms of customer satisfaction and sales growth. Details of an empirical research with logistics service providers in Hong Kong are reported in this paper. They study the following hypotheses: (1) Different logistics service bundles provided by LSPs can lead to cooperation in managing green logistics operations and in turn improved performance; (2) Different categories of greening capability in the logistics industry result in green operations and enhanced business performance that is increase in customer satisfaction and sales; and (3) Greening capability of LSPs is positively associated with their firm performance in terms of customer satisfaction and sales.

\section{Green Integration}

Green supply chain management focuses on manufacturing operations (product, process) in terms of waste (all forms), energy use, and resource use including material consumption. Kristianto and Helo investigate the implications of product architecture modularity for the operational economy of green supply chains with manufacturing process uncertainty. Their integrated model links traditional supply chain profit maximization with environmental and societal costs. They study the integration between: (i) between product \& manufacturing process design and ecology \& social principles, life cycle assessment, product life cycle extension \& reusability; and (ii) supply chain networks design and production line scheduling and more environmentally friendly products, processes and supply chains. They argue, "Green product design through product architecture modularity increases supply chains profit and product reusability. Therefore, product life cycle is extended, manufacturing lead times are reduced and disposal is minimized.

Logistics has become critical in global market and operations. It is particularly important for emerging economies such as Brazil, China, India and Russia. Considering the manufacturing 
growth in China, the logistics services are gaining attention in China for timely delivery of high quality and competitively priced products. This is due to outsourcing, ecommerce, and related freight activities, nevertheless, small to medium sized companies play a major role contemporary supply chains. Subramanian et al. studied the short term and long term benefits between logistics and cloud computing (CC) service providers in the Chinese medium and small logistics service providers through an empirical research. The major contribution of their study is to develop cost benefits analysis model based on innovation diffusion theory and validate it in the Chinese context. Considering the size and lack of resources and expertise for innovative technologies focusing on effective integration of operations of SMEs with focal companies, this paper proposes the integration of logistics and cloud computing service providers. The proposed research model includes three major dimensions of cloud computing in SME logistics providers: (1) perceived cost and benefits of CC, (2) perceived green benefits of CC, and (3) perceived need for CC adoption. The CC green benefits measurement model includes: costs and benefits (efficient IT, less investment in IT, reduce travels, enhanced resource utilization, reduced physical material usage and up to date technology).

\section{Green practices}

Remanufacturing plays a central role in the efforts of eco-efficiency, extended producer's responsibility and concern for the environment. This has led to focus on energy saving and pollution reduction. Zhu et al. introduced a research framework to indentify the barriers from a remanufacturing supply chain perspective including strategic and operational dimensions. They have applied a grey-based decision-making trial and evaluation methodology (DEMATEL) to study the cause-effect relationships among various implementation barriers by using responses from practitioners in a truck engine remanufacturer in China. The findings of this study indicate that there is a lack of: (i) strong financial support for remanufacturing technologies or equipment updates and innovation are key implementation barriers; (ii) quality standards of remanufactured products, availability of used truck engines and quality assurance and marketing of remanufactured engines are also major barriers. The following external barriers are considered in their study for remanufacturing: lack of information and quality, lack of costs and benefits from environmental efforts, lack of industrial standard for quality, taxes, arrival time and quantity of used engines, lack of customer awareness, low 
quality, poor dependability, lack overpricing scheme, and lack of quality assurance and aftersales service.

Companies around the world started recognizing that sustainability should be from all the three major perspectives, economic, social and environmental. However, many have attempted to achieve balance among them as a short-term focus. For example, environmental and social objectives have a long-term return. Because of the globalization of market and operations, the volume of goods exchanged through sea transport is huge and this highlights the importance of maritime industry's commitment to green supply chain. Understanding the importance of this, Li et al. in their paper considered reuse of empty container in the maritime industry context. They developed a procedure to include empty and laden containers considering both volume and weight as well as with empty container storage cost to enhance green effort. They highlight the importance of collaborative approach to empty container repositioning and reuse for maximizing the profit. They conclude that empty container reuse requires supply chain collaboration, in particular greening activities is bound to add value to a shipping supply chain.

Green supply chain management is the key activity that depends on relationships and supplier management. In order to achieve green supply chain management, it is essential that suppliers support the effort of greening through implementing suitable strategies, tactics and operations that will protect the environment at the upstream side of the supply chains. Dai et al. examine how influence of rivalry and stakeholder pressure motivates firms to implement green practices. The study brings in the role of competition and its role in integration of green issues with suppliers. Their attempt involved three levels of suppliers in green supply practices. The role of top management support has been highlighted to effectively react to competitive pressures and in turn implementing green supply chain management practices. They have tested their model interviewing a sample of supply chain professionals. They conclude that environmental pressure from rivals and stakeholders impact green supply chain management effort through top management support for environmental initiatives.

In the recent years, quality management has not been given due attention, particularly in greening supply chain or green supply chain management. Green supply chain management should be an integral part of quality management in any organizations. However, not much research reported in the literature on the relationship between quality management, 
environmental management maturity, external GSCM practices and environmental performance of firms. Jabbour et al. tested the new conceptual model based on the relationship between quality management, environmental management maturity, adoption of external practices of green supply chain management and green performance from Brazilian firms. The research method employed in this paper is based on a survey in which research experts in the subject are asked about their perception of relevant organizational aspects. The conceptual model includes the following major building blocks: quality management, green purchasing, status of environmental management, collaborate with consumers, and green performance. The results indicate that the quality management is an important antecedent for a firm's environmental management maturity which in turn influences the adoption of external GSCM practices and green performance.

Transportation is a major part of supply chain operations which means focusing on greening transportation (logistics) will support tremendously the green supply chain management effort and organizational performance for sustainable operations. Ramanathan et al. proposed a strategic approach to improve sustainability in transportation service procurement process. Their complete enumeration method is a useful approach to compare other methodologies. The major strategy employed in this paper is a full truck load transportation service with the objective of assuring sustainability in logistics. A carrier assignment problem is involved in truck load contract auction and two methodologies (complete enumeration and heuristics approaches) are proposed to solve the problem. The model has been tested with a real life case study.

\section{Green collaboration research framework}

The fundamental steps towards collaboration journey are transaction, cooperation, coordination and collaboration (Spekman et al., 1998). The pathway to green collaboration is based on green benefits, green relationship, green integration and green practices. The green collaboration research framework is developed by integrating fundamental steps of journey towards green collaboration and pathway to green collaboration. Basically this section identifies green transactions by relating green benefits with transaction, green cooperation by relating green relationship with cooperation, green coordination by relating green integration with coordination and finally green collaboration by relating green practices with collaboration. 


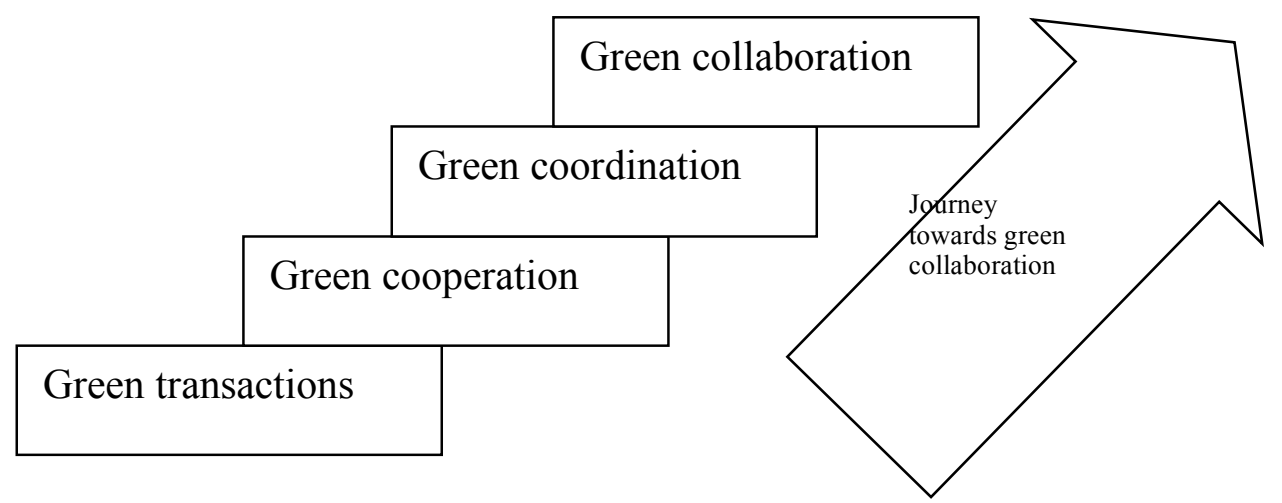

Figure 1: Green collaboration research framework

\section{Green transactions}

Green transaction includes green aspects in any transactions between a buyer and supplier. This includes consideration of green attributes that relates to short and long term sustainability in performing any activities within supply chain. Along with traditional attributes consideration of triple bottom triad is a starting point for researchers to proceed further. It is sparse to find studies which discuss the importance of green elements that takes place during multiple interactions within supply chain from upstream to downstream side. It is evident that few attempts were made to develop framework to capture and reveal selective green criteria from upstream to downstream supply chains. Still researchers need to think how to make green criteria friendly to people involved in transactions. Similarly, simple procedures and practices linking green benefits for green transactions need to be developed further. For example we had couple of papers by Ala-Harja and Helo and Azadi et al. discussed green benefits and not on how to carry out green transactions. Green transactions includes has multiple forms in supply chain management that can include, tangibles such as products, technology, dollars, people, etc. and intangibles such as trust, flexibility, good relationship, collaboration, knowledge, innovation and entrepreneurship. These aspects should be considered in developing conceptual and analytical models as well as conducting case study and empirical research.

\section{Green cooperation}

We refer green cooperation as a combined version of green relationship with cooperation. It is expected in the future that green cooperation builds long term relationship with the emphasis on the mutual benefits of partners in sharing revenues towards green practices. The 
first step towards green cooperation is to consider green aspects in choosing both upstream and downstream members who are willing to share green benefits. The cooperation is a mechanism to reduce risk and information asymmetry in order to meet performance objectives with less investment. The cooperation can occur in all areas of supply chain management including product development, procurement, planning and forecasting, information technology, resources (both financial and non-financial), communication and contracts. So far studies have discussed buy back contract, quality flexibility contract, pricediscount contract, revenue sharing contract and cooperative contract in traditional context and to certain extent in the green context. The green cooperation involves working together on common projects and objectives by considering green issues and long term relationship. However, there is no equity when it comes to sharing outcomes which means there is a disparity depending upon the partnering firms and their participation in adding value to customers and creating wealth. The cooperation employs a long-term contract to enforce most productive way of matching demand and supply. Hence it is not well known how the two aspects namely green relationship and cooperation are connected. The factors (variables and parameters) that will define the cooperation for greening supply chain need to be identified and then develop a conceptual model/framework for in-depth understanding so that this can be modelled later on for the implementation using appropriate optimization. In this special issue we had couple of papers by Luo et al. and Lun et al. discussing more about green relationship especially the influence of cultural aspects on firm's green performance and green inclinations of firms, green capability and performance in logistics sector respectively. In the future we expect many research will take place to understand the role of soft element relationship on mutual agreements between buyer and seller.

\section{Green coordination}

Green coordination is the combination of green integration and coordination. Basically green coordination needs green business continuity plans and process reengineering studies to achieve synergy. Horizontal integration between multiple supply chains to effectively use the resources is the green way to avoid wastages for the better future. Achieving ambidexterity between economic outcomes and non-economic outcomes is a serious issue while considering green issues. Depending upon the stage at which the green system and process is in place, the nature of coordination will be defined taking into individual organizational characteristics and the external environment it operates. Further research on coordination for greening of supply chain should focus on the type and nature of information and resources 
sharing. Suitable attributes that will define the successful outcomes of coordination should be identified in order to determine the level of coordination for greening of supply chains. Analytical models with integration and cooperation variables can be developed in the future to evaluate the performance based on green cooperation. More empirical and case study research will build green cooperation theories and understanding. Two papers in our special issue namely Kristianto and Helo and Subramanian et al. discussed the green integration in the manufacturing and logistics scenario. As per Kristianto and Helo, integration of product architecture modularity into design and manufacturing will contribute to reusability and green issues. Similarly, Subramanian et al. analyzed the cost and green benefits based on the integration of logistics and cloud service providers.

\section{Green collaboration}

Green collaboration is the combination of green practices and collaboration. Mostly macro level studies exist in the green incentives context. It is not well known how to motivate supply chain members to engage in green collaboration and capture green benefits across the breadth of supply chain. Similarly, how can each member within supply chain aim to balance short term and long term benefits under collaborative mode of operation. Still researchers need to dig further and see what types of incentives would be suitable for supply chain members to accommodate green aspects. Furthermore, out of box researches to challenge conventional practices of greening supply chain management through collaboration, that is for better outcomes, but at the same time reduced investment and time to achieve intended green performance is essential. For green collaboration to materialize at all levels (strategic, tactical and operational)it needs commitment from all members and perhaps changes in information and resource sharing and that too early on in the process for ensuring green supply chain management outcomes. As mentioned modeling and measuring intangibles are challenging. Therefore, we have to exercise caution in determining the factors that will decide the level of cooperation, coordination and that too along the line of greening supply chain through appropriate collaboration and incentives. Mathematical and simulation models can be developed for making investment decisions and that too considering the product life cycle. The strategic dimension is critical in deciding the long-term working together such as collaboration for a suitable green supply chain management and practices. This special issue has most of the papers related to the green practices to achieve green collaboration than other stages of collaboration. The prominent practices discussed in the special issue are as follows: 
remanufacturing practice and importance of collaboration to overcome barriers in an emerging economies context by Zhu et al. In the forward logistics context two papers by Li et al. and Ramanathan et al. discussed the relevance of collaborative approach. In Li et al. work they emphasized on positioning and reuse of empty container in the maritime context and Ramanathan et al. proposed two methodologies to improve the sustainability in the full truck load service procurement process. The antecedents to implement green practices by upstream supply chain members have been discussed by Dai et al. The vitality of quality practices to green the supply chain has been discussed by Jabbour et al. Few papers in our special issues discussed practices to improve collaboration. This is only the beginning and still a long way to go to really understand pathways to green collaboration. The summary of special issue papers based on our research framework is given below in table 1

Table1: Summary of special issue papers

\begin{tabular}{|c|c|c|c|c|}
\hline $\begin{array}{l}\text { Green } \\
\text { collaboration } \\
\text { stages }\end{array}$ & Authors & Research question & Contribution & Remarks \\
\hline \multirow[t]{2}{*}{$\begin{array}{l}\text { Green transaction } \\
\text { (Green benefits } \\
\text { and transaction) }\end{array}$} & $\begin{array}{l}\text { Ala-Harja and } \\
\text { Helo }\end{array}$ & $\begin{array}{l}\text { Analyse green logistics } \\
\text { decisions within the food } \\
\text { industry using a } \\
\text { performance } \\
\text { measurement } \\
\text { framework and to } \\
\text { compare alternative } \\
\text { scenarios using financial } \\
\text { and environmental } \\
\text { metrics. }\end{array}$ & $\begin{array}{l}\text { Provide framework } \\
\text { for supply chain } \\
\text { structure related } \\
\text { decisions, logistics } \\
\text { media decision and } \\
\text { planning and timing } \\
\text { decisions }\end{array}$ & $\begin{array}{l}\text { It is not clear how } \\
\text { green benefits } \\
\text { can be shared } \\
\begin{array}{l}\text { within } \\
\text { chain }\end{array}\end{array}$ \\
\hline & Azadi et al. & 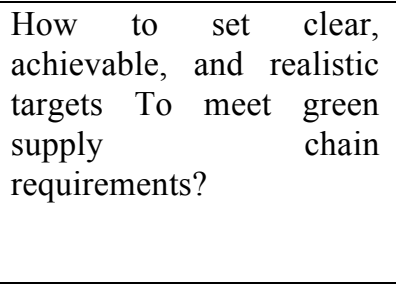 & $\begin{array}{l}\text { propose two data } \\
\text { envelopment } \\
\text { analysis (DEA) } \\
\text { approaches to find } \\
\text { targets for } \\
\text { two-stage network } \\
\text { structures }\end{array}$ & $\begin{array}{l}\text { Practical issues } \\
\text { need to be related } \\
\text { to the model to } \\
\text { improve the } \\
\text { models usage in } \\
\text { understanding } \\
\text { green benefits }\end{array}$ \\
\hline \multirow[t]{2}{*}{$\begin{array}{l}\text { Green } \\
\text { cooperation } \\
\text { (Green } \\
\text { relationship and } \\
\text { cooperation) }\end{array}$} & Luo et al. & $\begin{array}{l}\text { How buyer-seller } \\
\text { relationship, competitive } \\
\text { environment } \\
\text { and guanxi affect Chinese } \\
\text { manufacturers' decision } \\
\text { to implement Green } \\
\text { Supply } \\
\text { Collaboration (GSCC) }\end{array}$ & $\begin{array}{l}\text { Study contextually } \\
\text { buyer-seller } \\
\text { relationships in } \\
\text { GSCC }\end{array}$ & $\begin{array}{l}\text { Micro details of } \\
\text { cooperation and } \\
\text { relationship is } \\
\text { missing. How far } \\
\text { it is applicable to } \\
\text { other industries? }\end{array}$ \\
\hline & Lun et al. & $\begin{array}{l}\text { What are the categories } \\
\text { of greening capability in } \\
\text { logistics service providers } \\
\text { (LSPs)? What are the } \\
\text { performance outcomes of } \\
\text { LSPs' greening } \\
\text { capability? }\end{array}$ & & \\
\hline \multirow{2}{*}{$\begin{array}{l}\text { Green } \\
\text { coordination } \\
\text { (Green }\end{array}$} & $\begin{array}{l}\text { Kristianto and } \\
\text { Helo }\end{array}$ & & & \\
\hline & Subramanian et al & & & \\
\hline
\end{tabular}




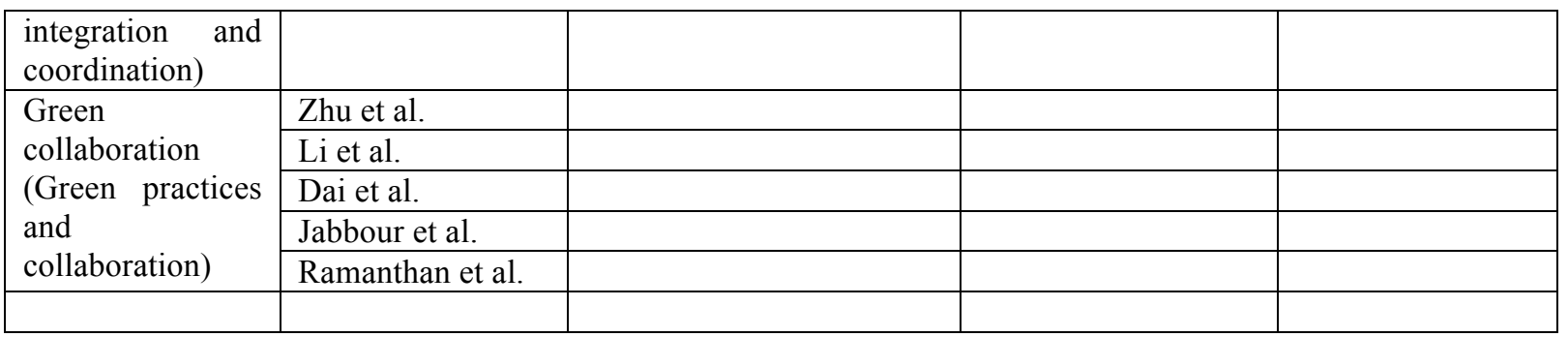

\section{Concluding remarks}

We have received about 40 submissions for the special issue. Each paper was reviewed by at least two experts and most papers have gone through two cycles of revisions. About 100 anonymous reviewers who read the papers and submitted their reviews on time and without their generous help and support, we would not have completed this special issue.

Reviewing the papers which appear in the special issue and their research limitations, the following research topics can be considered for further investigations:

1. The effect of buyer-supplier relationships on collaboration between companies of different locations or countries (and comparisons) and its impact on green supply chain management. Also, other determinants of buyer-supplier relationships in green supply chain management should be considered.

2. Sustainable/green food supply chain offers a great scope for further research considering the perishability, health reasons and government policies \&regulations.

3. Develop analytical and simulations models at the implementation/operational level decision making for greening supply chain through collaboration and incentives. Tools or techniques such as game theory, fuzzy logic, linear and integer-programming as well as simulation can be utilized for optimization.

4. Global operational factors such as product pricing, import duty, tax and environmental regulations should be considered in green supply chain decisions.

5. While studying the integration of cloud computing and its effect on relationships for green logistics, the following of logistics factors should be considered: freight 
forwarding, customs clearance, and sea freight shipment on door-to-door or to port service companies.

6. Multi-criteria decisions making models can be developed for extending the models reported in the special issue so that other real life factors can be considered in order to increase the scope of the applications of such models in green supply chain development.

7. Studies reported have some limitations with reference to sample size and geographical coverage and the hypotheses explored. Also, both the financial and non-financial performance objectives should be considered as a part of future research effort.

8. How to prioritize the efforts and focus areas in organizations for greening supply chain based on the value-added activities? Whether a company should focus on remanufacturing or recycling, procurement, process improvement, and logistics and so on. Depending upon the core business process, companies should decide the effort or initiatives for greening the supply chain.

The following are some of the future research directions in greening supply chain management:

- Green supply chain collaboration and incentives are combination of intangibles and tangibles which demands further investigations on performance measures and metrics for measuring greening, supply chain collaboration, outcomes, and incentivization.

- There are many empirical and case study articles in the literature to deal with the importance of green supply chain collaboration and incentives, but very limited research on the implementation of them with suitable modeling and analysis including suitable constraints and objective functions. For example, agency theory can be applied for optimal profit sharing between stakeholders in green supply chain effort and management.

- Developing cost management models for green supply chain management incorporating collaboration and incentives will help make more informed decisions. Also, trade-off between quality and cost may not support green supply chain 
management in short-term. Therefore, long-term costs and benefits should be considered while evaluating alternatives for collaboration and incentives for green supply chain management.

- Quality management models and standards should be developed incorporating the dimension of collaboration and incentives.

- The government policies and industrial regulations in different countries could influence the success of collaboration and incentive levels. These need to be incorporated in future studies of green supply chain management.

- Analytical models that would clearly provide costs and benefits both in short-term and long-term should be developed for making decisions related to green initiatives in supply chain management.

- The integration of greening efforts between small and medium enterprises and focal companies need to be investigated in detail with reference to collaboration and incentives.

- An integrated green supply chain model incorporating the costs and benefits of collaboration among stakeholders along the whole supply chain operations starting from the extract of the raw materials until the product goes back to the earth.

- The aspects of human dimension have not been given due attention in the study of greening of supply chain management, including the role of different managers in an organization. This needs further research and development to be successful with supply chain collaboration and motivation.

- The social element has been given limited importance in most of the greening activities in supply chain management. This offers a great scope for further research.

- The organizational structure that would support the collaboration for greening supply chain needs further investigation for modeling and analysis. 
- Big data and business analytics are yet to be looked into when developing frameworks for greening supply chain through collaboration, incentives and other initiatives. Multi-national or international studies and social media data can be utilized to determine critical success factors for greening supply chain.

We hope this special issue will be a starting point for moving forward with the research to address the above issues for greening supply chain management.

\section{Acknowledgements}

Our sincere thanks and appreciation go to all the reviewers and the Editor-In-Chief, Professor Jiuh-Biing Sheu for their excellent support throughout the editing of this special issue.

\section{References}

Vachon, S., \&Klassen, R. D. 2008. Environmental management and manufacturing performance: The role of collaboration in the supply chain. International Journal of Production Economics, 111(2): 299-315.

Vachon, S. 2007. Green supply chain practices and the selection of environmental technologies. International Journal of Production Research, 45(18-19): 4357-4379.

Azevedo, S. G., Carvalho, H., \& Cruz Machado, V. 2011. The influence of green practices on supply chain performance: A case study approach. Transportation Research Part E: Logistics and Transportation Review, 47(6): 850-871.

Cheng, J.-H. 2011. Inter-organizational relationships and knowledge sharing in green supply chains-Moderating by relational benefits and guanxi. Transportation Research Part E: Logistics and Transportation Review, 47(6): 837-849.

De Giovanni, P. 2011. Environmental collaboration in a closed-loop supply chain with a reverse revenue sharing contract. Annals of Operations Research, 220(1): 135-157.

Gavronski, I., Klassen, R. D., Vachon, S., \&Nascimento, L. F. M. d. 2011. A resource-based view of green supply management. Transportation Research Part E: Logistics and Transportation Review, 47(6): 872-885.

Sheu, J.-B. 2011. Bargaining framework for competitive green supply chains under governmental financial intervention. Transportation Research Part E: Logistics and Transportation Review, 47(5): 573-592.

Sheu, J.-B., \& Talley, W. K. 2011. Green Supply Chain Management: Trends, Challenges, and Solutions. Transportation Research Part E: Logistics and Transportation Review, 47(6): 791-792.

Green, K. W., Zelbst, P. J., Bhadauria, V. S., \& Meacham, J. 2012. Do environmental collaboration and monitoring enhance organizational performance? Industrial Management \& Data Systems, 112(2): 186-205. 
Koh, S. C. L., Gunasekaran, A., \& Tseng, C. S. 2012.Cross-tier ripple and indirect effects of directives WEEE and RoHS on greening a supply chain. International Journal of Production Economics, 140(1): 305-317.

Dangelico, R. M., \&Pontrandolfo, P. 2013. Being 'Green and Competitive': The Impact of Environmental Actions and Collaborations on Firm Performance. Business Strategy and the Environment: DOI: $10.1002 / \mathrm{bse} .1828$

Trencher, G. P., Yarime, M., \& Kharrazi, A. 2013. Co-creating sustainability: cross-sector university collaborations for driving sustainable urban transformations. Journal of Cleaner Production, 50: 40-55.

Chen, P.-C., \& Hung, S.-W. 2014. Collaborative green innovation in emerging countries: a social capital perspective. International Journal of Operations \& Production Management, 34(3): 347-363.

Helen Walker, P. S. S. P., Prajogo, D., K.Y. Tang, A., \& Lai, K.-H. 2014. The diffusion of environmental management system and its effect on environmental management practices. International Journal of Operations \& Production Management, 34(5): 565-585.

Jabbour, A. B. L. d. S., Jabbour, C. J. C., Latan, H., Teixeira, A. A., \& de Oliveira, J. H. C. 2014. Quality management, environmental management maturity, green supply chain practices and green performance of Brazilian companies with ISO 14001 certification: Direct and indirect effects. Transportation Research Part E: Logistics and Transportation Review, 67: $39-51$.

Ramanathan, U., Bentley, Y., \& Pang, G. 2014. The role of collaboration in the UK green supply chains: an exploratory study of the perspectives of suppliers, logistics and retailers. Journal of Cleaner Production, 70: 231-241.

Sheu, J.-B. 2014. Green Supply Chain Collaboration for Fashionable Consumer Electronics Products under Third-Party Power Intervention-A Resource Dependence Perspective. Sustainability, 6(5): 2832-2875.

Spekman,R., Kamauff,J. \& Myhr,N. 1988. An empirical investigation into supply chain management: a perspective on partnerships, Supply Chain Management, 3(2), 53-67. 